\section{Gore-tex: A new prosthesis for vascular access}

The need for vascular access for haemodialysis in patients with absent peripheral vessels has led to the development of various surgical techniques. New vascular channels have been formed using free autogenous vein grafts, vein homografts, and the Sparks mandril and modified bovine heterografts. Some of these techniques have disadvantages, and this preliminary study was designed to assess the value of Gore-Tex expanded polytetrafluoroethylene (PTFE) vascular grafts as a means of providing a secondary form of vascular access.

\section{Patients, methods, and results}

Five patients on chronic haemodialysis (cases 1-5) and one patient requiring hyperalimentation after extensive small bowel resection for Crohn's disease (case 6) were grafted (see figure). Two patients (cases 1 and 2) had stenosis of the venous return from wrist arteriovenous fistulae. In both straight bypass PTFE grafts were inserted with the distal anastomosis at the fistula and proximal anastomosis to a vein near the cubital fossa. In case 3 a forearm loop graft was used with anastomosis to the brachial artery in the cubital fossa and to an adjacent vein. The remaining patients (cases 4-6) had forearm loop grafts with arterial take-off in the upper arm. The graft material used for all cases was expanded PTFE of high porosity with nominal fibril lengths of $30 \mu \mathrm{m}$. The internal diameter was $6 \mathrm{~mm}$ and graft lengths varied from $19 \mathrm{~cm}$ to $58 \mathrm{~cm} .6 / 0$ Ethiflex was used for all anastomoses. Prophylactic antibiotic cover was given for four days from the time of operation. Grafts were used for cannulation three weeks after insertion. The longest period of follow-up was four months.

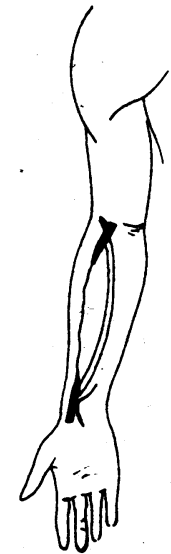

Straight graft (coses 1 and 2 )

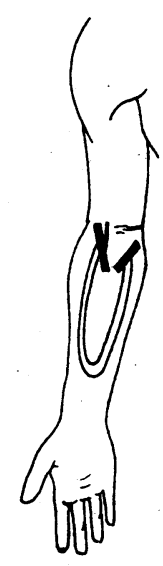

Loop graft with foreorm toke of (case 3)

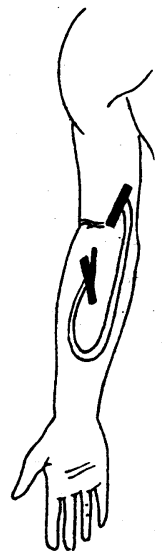

Loop graft with upper orm toke off (cases 4-6)
Gore-Tex PTFE graft forms for vascular access in six patients.

At the time of writing four grafts were being used for cannulation (cases $1,4,5$, and 6 ). The graft in case 2 underwent occlusion within the first week after operation. It became infected and was removed seven weeks after insertion. The other patient (case 4), who had a failing kidney transplant, died of cytomegalovirus infection 10 days after insertion of a PTFE graft which remained patent to the time of death.

Cannulation of the grafts was simple and there was no increased tendency to bleed on withdrawal of the cannulae and no aneurysm formation at the puncture sites. Except in case 2 there was no evidence of infection.

Graft angiograms after four weeks showed that the lumen remained regular and smooth, though with loop forms there is a tendency for a crease to appear on the concavity of the apex of the loop.

\section{Discussion}

The physical properties of expanded PTFE vascular grafts suit them for anastomosis to the medium and small sized vessels encoun- tered in vascular access surgery. The material does not fray, and as it is very pliable accurate anastomoses can be made.

Unlike bovine grafts, PTFE grafts of the type used in this pilot study probably develop a neointima, and this may be a factor contributing to their high patency rate even in comparatively low-flow sites. ${ }^{1-3}$ The one failure may have been due to faulty surgical judgment, which resulted in inadequate flow in the prosthesis. Infection appeared after the occlusion.

Expanded PTFE grafts are an acceptable alternative to autogenous saphenous veins and their use obviates the need for removing a vein which is tedious and leaves an extensive scar. In this centre it is considered preferable to provide forearm rather than upper arm or thigh vascular access and the availability of grafts of suitable diameters facilitate this policy.

I thank W L Gore and Associates (UK) Ltd for supplying the grafts; and Dr I S Robson and Mr I B Macleod for permission to report on their patients. The advice of Professor Sir Michael Woodruff is gratefully acknowledged.

1 Smith, D E, et al, fournal of Thoracic and Cardiovascular Surgery, 1975, $69,589$.

2 Campbell, C D, Goldfarb, D, and Roe, R, Annals of Surgery, 1975, 182 138.

3 Matsumoto, H, et al, Surgery, 1973, 74, 519.

University Department of Surgery and Nuffield Transplantation Surgery Unit, Western General Hospital, Edinburgh EH8 9AG A MCL JENKINS, MB, FRCs, lecturer

\section{Antinuclear antibodies in patients on lithium carbonate}

Many drugs are known to produce a syndrome like systemic lupus erythematosus (SLE) ${ }^{1}$ And psychiatric disease may also be the presenting feature of SLE. ${ }^{2}$ Recently it has been suggested that lithium carbonate may have a tendency to produce antinuclear antibodies. ${ }^{3}$ We report here the first controlled clinical study of this finding.

\section{Patients, methods, and results}

Fifty patients attending a busy non-acute psychiatric hospital who had all been taking lithium carbonate for two months to 10 years underwent blood estimation of antinuclear factor (ANF). Fifty patients matched for age, sex, and disease acted as controls. The diagnoses were made by experienced medical staff not concerned in this study. Data on each patient were collected retrospectively after the specimens reached the laboratory. ANF was estimated using a standard immunofluorescence technique. Other anti-tissue antibodies were observed. Examination for DNA antibodies was performed using the Crithidia method. ${ }^{4}$ The laboratory did not know which group the samples came from.

The average ages in the test and control groups were 46 years and 44 years respectively, with comparable age ranges and sex ratios (test group 19 men; control group 16 men). All but six patients in the test group and 12 in the control group were suffering from psychotic depression or manic-depressive psychosis. None of the controls were positive for ANF. Of the 50 patients in the test group 11 were positive for ANF (see table), and none of these had anti-DNA antibodies. In two ANF-positive patients ANF subsequently disappeared while treatment remained unchanged. There were no cases of clinical allergy to lithium carbonate, and no patient showed physical signs of SLE on examination. One woman (case 10) had true SLE that had been diagnosed many years before lithium treatment began. She developed a mild but definite exacerbation of the disease, with facial skin changes and pruritus. Patients in both groups received other drug treatment and electric convulsion therapy in roughly comparable regimens. The incidence of parietal cell 
Details of patients positive for $A N F$

\begin{tabular}{|c|c|c|c|c|c|c|c|}
\hline Case No & $\begin{array}{l}\text { ANF staining } \\
\text { pattern }\end{array}$ & Sex & Age & $\begin{array}{l}\text { Length of time } \\
\text { on lithium }\end{array}$ & 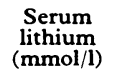 & Other drugs & $\begin{array}{l}\text { Clinical } \\
\text { side effects }\end{array}$ \\
\hline $\begin{array}{l}1^{*} \\
2 \\
3 \\
4^{*} \\
5 \\
6 \\
7 \\
8 \\
9 \\
10 \\
11\end{array}$ & $\begin{array}{l}\text { Weak } \\
\text { Weak } \\
\text { Weak } \\
\text { Weak } \\
\text { Homogeneous } \\
\text { Homogeneous } \\
\text { Homogen } \\
\text { Homogeneous } \\
\text { Nucleolar } \\
\text { Peripheral } \\
\text { Speckled } \\
\text { Homogeneous }\end{array}$ & $\begin{array}{l}\mathrm{F} \\
\mathrm{F} \\
\mathrm{F} \\
\mathrm{F} \\
\mathrm{M} \\
\mathrm{M} \\
\mathrm{F} \\
\mathrm{F} \\
\mathrm{M} \\
\mathrm{F} \\
\mathrm{F}\end{array}$ & $\begin{array}{l}53 \\
60 \\
52 \\
62 \\
60 \\
51 \\
27 \\
63 \\
60 \\
57 \\
52\end{array}$ & $\begin{array}{l}3 \text { years } \\
4 \text { years } \\
7 \text { months } \\
6 \text { months } \\
2 ! \text { years } \\
2 \text { months } \\
11 \text { months } \\
8 \text { months } \\
8 \text { months } \\
1 \text { year } \\
2 \text { years }\end{array}$ & $\begin{array}{l}0 \cdot 6 \\
0 \cdot 5 \\
0 \cdot 8 \\
1 \cdot 1 \\
0 \cdot 8 \\
0 \cdot 4 \\
1 \cdot 0 \\
0 \cdot 75 \\
0 \cdot 7 \\
0 \cdot 8 \\
0.9\end{array}$ & $\begin{array}{l}\text { Imipramine, chlorpromazine } \\
\text { Clomipramine } \\
\text { Trifluperazine, chlorpromazine } \\
\text { None } \\
\text { Clomipramine } \\
\text { None } \\
\text { Clomipramine } \\
\text { Imipramine } \\
\text { Impramine } \\
\text { Chlorpromazine, amitryptiline } \\
\text { Haloperidol }\end{array}$ & $\begin{array}{l}\text { None } \\
\text { None } \\
\text { None } \\
\text { Bruising } \\
\text { None } \\
\text { None } \\
\text { Bruising } \\
\text { None } \\
\text { None } \\
\text { True SLE } \\
\text { None }\end{array}$ \\
\hline
\end{tabular}

* These patients reverted to being negative for ANF and were therefore excluded from statistics.

Conversion: SI to traditional units-Lithium: $1 \mathrm{mmol} / 1 \approx 6.95 \mathrm{mg} / 1$.

antibodies in the patient taking lithium was twice the incidence in the control group.

\section{Comment}

No cases of ANF or SLE in patients on lithium carbonate have been reported to the Committee on Safety of Medicines or the Adverse Drug Reaction Information Service. ${ }^{5}$ Our findings indicate an $18 \%$ incidence of this phenomenon in lithium takers. The absence of antiDNA antibodies in these patients indicates that they did not have true SLE. The management of these asymptomatic patients with abnormal immunological test results is difficult, since in many cases a change of treatment is not practicable and serious disabilities may develop ${ }^{1}$ from drug-induced SLE reactions. In view of the length of clinically uncomplicated lithium treatment, the drug was not stopped in these patients but scrutiny continued.

The incidence of parietal cell antibodies may have clinical relevance in view of the gastrointestinal symptoms lithium carbonate produces.

This controlled study confirms the initial observation that antinuclear antibodies are more common in patients taking lithium carbonate than in controls. Patients ingesting this drug may be at risk.

We thank the consultants and nursing staff of the Midland Nerve Hospital for allowing us to study their patients, and Sister Quinton for her help in collecting blood samples.

Requests for reprints should be addressed to: Dr A P Presley, General Hospital, Steelhouse Lane, Birmingham B4 6NH.

${ }^{1}$ Harpey, J P, Adverse Drug Reaction Bulletin, 1974, 43, 410.

2 Bennett, et al, British Medical fournal, 1972, 4, 342.

3 Johnstone, E C, and Whaley, K, British Medical fournal, 1975, 2, 724.

4 Aarden, L A, de Croot, E R, and Feltkampt, E W, Annals of the New York Academy of Sciences, 1975, 254, 505.

5 Davies, D M, personal communication, 1975.

Midland Nerve Hospital, Edgbaston, Birmingham 15

A P PRESLEY, BSC, MB, senior house officer in psychiatry

A KAHN, MB, CHB, senior house officer in psychiatry

Rheumatism Research Wing, Queen Elizabeth Medical Centre, Edgbaston, Birmingham 15

N WILLIAMSON, MB, BS, lecturer in experimental pathology, University of Birmingham healthy adult who developed CMV infection complicated by severe ocular involvement.

\section{Case report}

A 39-year-old previously healthy woman presented in November 1975 with a two-week history of generalised malaise, bilateral loin pain, urinary frequency, and nocturia without dysuria associated with rigors, anorexia, and weight loss. She had noticed discoloration of her urine, and her symptoms had failed to respond to treatment with co-trimoxazole and then ampicillin.

On examination she was feverish $\left(38^{\circ} \mathrm{C}\right)$ with abdominal tenderness. Fundoscopy showed nothing abnormal. Investigations showed: white blood count $6.8 \times 10^{9} / 1\left(6800 / \mathrm{mm}^{3}\right)$ with $23 \%$ neutrophils, $66 \%$ lymphocytes, and $7 \%$ atypical lymphocytes. There was mild hyponatraemia (serum sodium $129 \mathrm{mmol} / \mathrm{l}(296 \mathrm{mg} / 100 \mathrm{ml}))$ and considerable derangement of liver function with bilirubin $17 \mathrm{~mol} / 1(1.0 \mathrm{mg} / 100 \mathrm{ml})$, alkaline phosphatase $203 \mathrm{U} / 1$ (normal 20-85 U/1), Lactate dehydrogenase 1666 IU/1 (normal 72-395 IU/1), serum aspartate aminotransferase $150 \mathrm{U} / 1$ (normal 9-43 U/1), and serum alanine aminotransferase $163 \mathrm{U} / 1$ (normal $5-41 \mathrm{U} / \mathrm{l}$ ). Total proteins were $69 \mathrm{~g} / \mathrm{l}$ (normal $60-80 \mathrm{~g} / \mathrm{l}$ ), albumin $46 \%$ (normal $57-68 \%$ ), and $\lambda$-globulin $20 \%$ (normal $9 \cdot 8-18 \cdot 2 \%$ ). Chest $x$-ray pictures and intravenous pyelogram were normal. The following investigations also gave negative results: repeated culture of urine and blood; Paul-Bunnell, Monospot, and HA antigen test on several occasions; paired serology for Epstein-Barr virus, toxoplasmosis, mycoplasmal infection, brucellosis, salmonellosis, leptospirosis, syphilis, and herpes simplex; and urinary viral studies. A diagnosis of acute CMV infection was established by serial complement-fixing antibody tests, the titres rising from $1 / 16$ two weeks after the onset of illness (on admission) to $1 / 256$ at three weeks, $1 / 512$ at four weeks, and falling to $1 / 128$ at 10 weeks.

After admission she had several further rigors and after four days developed a generalised maculopapular rash attributed to ampicillin. This settled and within a week she was apyrexial though her severe generalised malaise persisted. After four weeks she complained of deteriorating vision. Repeat fundoscopy showed a pin-point chorioretinitis mainly along the retinal veins with macula sparing, accompanied by irregular sheathing of adjacent blood vessels (see figure). A keratoconjunctivitis sicca with superficial punctate keratitis was also discovered. When last reviewed in February 1976, she was still tired and lethargic and had persisting visual symptoms

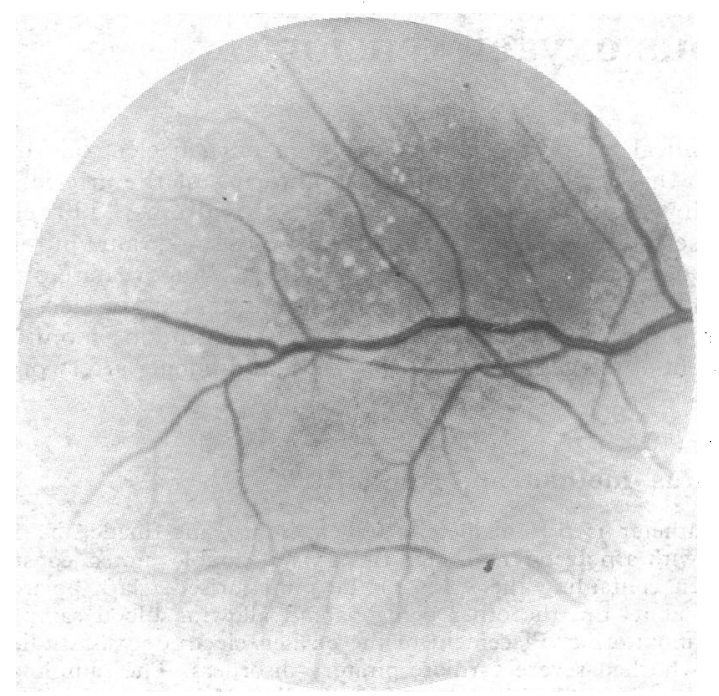

Pin-point chorioretinitis and irregular sheathing.

\section{Ocular involvement in cytomegalovirus infection in a previously healthy adult}

Although common in infancy, infection with cytomegaloviruses (CMV) causing chorioretinitis has been reported in only six adults. ${ }^{12}$ In each case the patient had a debilitating disease and was receiving either steroids or cytotoxic drugs. We describe here a previously 